\title{
Pattern of eye diseases among welders in a Nigeria community
}

\author{
*Ajayi Iyiade A, Omotoye Olusola J \\ Department of Ophthalmology, University Teaching Hospital, Ado-Ekiti Ekiti state, Nigeria
}

\begin{abstract} radiation. segments examination, test of stereopsis and macular function. respectively) in arc welders than in gas welders. among welders.

Key words: eye disorders, welders, Nigeria

\section{Introduction}

Welding is a widely used process. It is one of the most intense artificial sources of invisible and visible optical radiation, with ultraviolet $\mathrm{B}$ being the main actinic component ${ }^{1-4}$. Gas and arc welding are the commonest types of welding practiced in the less industrialized world ${ }^{5}$

Different adverse biologic effects stem from visible light, near and far infrared and the A, B and $\mathrm{C}$ divisions of ultraviolet radiation all of which are emitted in various degrees by the various types of welding ${ }^{7}$. Long term chronic exposure to ultraviolet radiation is associated with conditions like pterygia, pingueculae, band-shaped keratopathy and climatic droplet keratopathy ${ }^{8}$. Thermal burns from hot metal can also occur when welding and contribute to the risk of developing skin and ocular damage ${ }^{14}$. Erhabor ${ }^{5}$ in a study of the pulmonary functions of 54 gas welders in Ile-Ife reported that $51.1 \%$ of the gas welders complained of eye irritation.
\end{abstract}

Background: Welders have been identified as a high risk group for eye disorders due to their exposure to ultraviolet

Objective: To determine the prevalence and types of eye diseases amongst welders in Ile-Ife, Osun state.

Methods: This is a cross sectional descriptive study of 405 consenting welders. Information on socio-demographic characteristics was obtained using a pre-tested proforma and all subjects had visual actuity test, anterior and posterior

Results: Two hundred and seventy five $(67.9 \%)$ of the respondents were arc welders, $99(22.5 \%)$ were gas welders while $39(9.6 \%)$ utilized both welding techniques. The age of the respondents ranged from 16 years to 80 years with a mean of $38 \pm 13$ years. Conjunctival degenerative disorders like pingueculum $(50.1 \%)$ and pterygium(17.5\%) constituted the commonest eye disorders among the welders. There were 6 blind eyes of 5 welders with pigmentary maculopathy accounting for the single case of bilateral blindness. There is a greater odd in developing pingueculum and Pterygium $(\mathrm{OR}=1.015,1.039$

Conclusion: Pingueculum, Pterygium, corneal opacity, and pigmentary macular deposits were the common eye disorders

African Health Sciences 2012; 12(2): 210 - 216 http://dx.doi.org/10.4314/ahs.v12i2.21

\footnotetext{
*Correspondence author:

Dr Ajayi, Iyiade Adeseye

Department of Ophthalmology

University Teaching Hospital

PMB 5355

Ado-Ekiti state, Nigeria

Telephone: +2348034311540

E-mail: iviseye2005@yahoo.com
}

The mainstay of ocular protection from welding arc radiation is filter placed within the welder's helmet. Historically these filters have been made of infrared absorbing green glass ${ }^{22}$.

The few available studies on this subject were done in the southeastern region of Nigeria and comprised fewer welders with other industrial workers about two decades $\operatorname{ago}^{29,31}$. The use of welding has increased in recent years ${ }^{5}$ and there is no study from the southwestern region of Nigeria.

The findings of this study would provide a recent baseline data for the southwestern region which can be used to develop policies and strategies for promoting eye health and preventing welding related occupational hazards.

\section{Methods}

This is a cross-sectional study of all the Welders in Ile-Ife. There are a total of 486 welders in Ile-Ife. Thirty-six non-consenting respondents were excluded.

A questionnaire was administered to each respondent by face to face interview, after explaining the procedure and the need to conduct the study. The interview was conducted in English language, with language translation in Yoruba when necessary. The interview elicited information on Personal data, 
welding history, social history and ocular history. All welders had visual acuity test in the open field in daylight using the Snellen's chart (or illiterate E chart) placed at 6 meters. Each eye was tested separately unaided and further testing with pinhole was done in cases where visual acuity was less than $6 / 6$. Visual acuity in the better eye of $6 / 6-6 / 18$ was considered to be normal, $<6 / 18-6 / 60$ was classified as visual impairment and $<6 / 60-3 / 60$ as severe visual impairment while visual acuity less than 3/60 was classified as blindness.

The TNO test chart was used to examine for stereopsis in each respondent. With the subject wearing the red-green spectacles the first three plates were used to establish the presence of stereoscopic vision. Ability to perceive depth with the first 3 plates were recorded as normal, while inability to perceive depth was recorded as abnormal.

Visual field was assessed in each respondent by the principal investigator, using the confrontational method compared with examiners. The author had undergone an automated perimetry to confirm a normal central visual field. Any deviation from examiner's field was recorded as abnormal. Extraocular muscle activity was tested in all directions of gaze, seeking for any paresis or paralysis of the extraocular muscles. Diplopia was sought for in all directions of gaze.

Anterior segment examination was done with a bright pen torch. Binocular loupe (x 3.5) was used for magnification. The upper and lower lids were examined for deformities. Fundoscopy was carried out on all the respondents using the Welch Allyn professional direct ophthalmoscope, in a relatively darkened common room of the welders' zonal meeting house. Dilated fundoscopy was conducted in persons with reduced vision or hazy media precluding detailed view of the fundus. Macular function was assessed with Amsler grid in all subjects. With the patient fixating steadily at the central spot of the grid, a report of all the lines as being straight and complete was reported as normal while a report of distorted or missing line was considered abnormal.

Tonometry was carried out only on respondents with suspicious optic discs, those with cup/disc ratio $\geq 0.5$ and all respondents older than 40 years. A Perkin's applanation tonometer was used for this purpose after instilling anaesthetic drop (Tetracaine Hcl 1\%) and staining the tear film with fluorescein strips checking one eye at a time.

A pilot study was carried out on 10 welders from Ilesa a neighbouring town, to assess the African Health Sciences Vol 12 No 2 June 2012 workability of the method and necessary modifications were made especially on the questionnaire. These subjects were exempted from the final analysis of the study.

Data were recorded and all statistical analyses were performed with commercially available computer program, Statistical Package for Social Science (SPSS) version 13.0. Data are expressed as Mean \pm Standard Deviation (SD) and frequency expressed as a percentage. The relationships between categorical data were analyzed using $x^{2}$ test. At the adopted confidence level of $95 \%$, a p value of 0.05 (i.e. $5 \%$ ) or less was considered to be significant. Yates's corrected chi square and the appropriate Fisher's exact $\mathrm{p}$ value were used where the value of any cell was less than 5 .

Ethical clearance was obtained from the Ethics and Research Committee of the Obafemi Awolowo University Teaching Hospitals Complex Ile-Ife. Consent was obtained from the leader of the Association of Welders in Ile-Ife. Voluntary consent was obtained from each respondent in the field.

\section{Results}

A total of 405 welders were examined out of which 402 were males $(99.3 \%)$ and three were females $(0.7 \%)$ giving a male to female ratio of $134: 1$. The age of the respondents ranged from 16years to 80 years. The mean age was $39 \pm 13$ years. Two hundred and seventy five $(67.9 \%)$ of the respondents were arc welders, 99(22.5\%) were gas welders while $39(9.6 \%)$ utilized both arc and gas welding techniques. The mean duration of weilding was $17 \pm 12$ years. Three hundred and eighty four $(94.8 \%)$ of the respondents had normal vision, 21 (5.2\%) had visual impairment, severe visual impairment $7(1.7 \%)$.

Only 39 welders used their protective eye device always, 116 used it occasionally while 250 never used any protective device. Refractive error accounted for $80 \%$ of the cases with visual impairment. After optical correction there were six blind eyes of five welders. The only one with bilateral blindness was a 48 year old arc welder who had bilateral pigmentary maculopathy. One of those with unilateral blindness had right eye enucleation as a result of work related eye injury; the three other cases were age related cataracts.

All the welders had normal stereopsis except for the 5 welders with blindness. 
Pingueculum (50.1\%), presbyopia (36.8\%), refractive errors $(25.2 \%)$, pterygium $(17.5 \%)$, cataract (11.6\%), cornea opacities (10.4\%), and Pigmentary macula changes $31(7.7 \%)$ were the common eye disorders seen among the welders examined. The peak age of occurrence of pterygium was in the third and fourth decade Most of the pterygia were located nasally. A statistically significant association was found between duration of practice of welding and the occurence of pterygium $(\mathrm{p}=0.02)$. Drusen in the welders spanned through all the age groups with the exception of those under 20 years of age who were relatively young in the profession. About $50 \%$ of them were in the age group between $31-40$ years. With Amsler grid assessment, none of the welders had a defective macular function apart from the single case of bilateral maculopathy. Other ocular findings are as shown in table 1 in comparison with other Nigerian studies. The mean intraocular pressure was $13 \mathrm{mmHg} \pm 4 \mathrm{mmHg}$.
Table 2 shows the influence of the type of welding technique on the ocular findings, after excluding those who utilize both types of welding techniques. Although no significant difference was found between those who have pingueculum and Pterygium, however, there is are greater odd in developing these disorders in arc welders than in gas welders. ( $\mathrm{OR}=1.015,1.039$.) The confidence interval including 1 means that there is no difference between arc and gas welders developing pingueculum and pterygium.

Cornea opacity, macular drusen and Pigmentary macular changes were significantly higher among the arc welders than the gas welders $(p<0.05)$. The odds in developing these conditions are greater than 1 and the confidence interval not including 1 means that the arc welders have a greater risk of developing these conditions than the gas welders. The specific age distribution of the eye disorders seen in the welders is shown in table 3.

Table 1: Type of eye diseases in the respondents

\begin{tabular}{lc}
\hline Type of eye disease & Frequency \\
\hline Pingueculum & $203(50.1 \%)$ \\
Presbyopia & $149(36.8 \%)^{*}$ \\
Refractive errors & $102(25.2 \%)$ \\
Pterygium & $71(17.5 \%)^{* *}$ \\
Glaucoma suspects & $48(11.9 \%)$ \\
Age related cataract & $43(10.6 \%)$ \\
Cornea opacity & $42(10.4 \%)^{* * *}$ \\
Pigmentary macula changes & $31(7.7 \%)$ \\
Macula drusen & $21(5.2 \%)$ \\
Ptosis & $7(1.7 \%)$ \\
Allergic conjunctivitis & $5(1.2 \%)$ \\
Presenile cataract & $2(0.5 \%)$ \\
Traumatic cataract & $2(0.5 \%)$ \\
Pseudogerontoxon & $2(0.5 \%)$ \\
Symblepharon & $1(0.2 \%)$ \\
Empty socket & $1(0.2 \%)$ \\
Cyst of Moll & $1(0.2 \%)$ \\
\hline
\end{tabular}

114 welders had more than 1 eye disorder. $* 52$ uncorrected, $* * 4$ unilateral; 1 double, $* * * 27$ unilateral

Table 2: Relationship between ocular findings and type of welding

\begin{tabular}{lllllll}
\hline $\begin{array}{l}\text { Ocular } \\
\text { finding }\end{array}$ & $\begin{array}{l}\text { Arc } \\
\text { welding }\end{array}$ & $\begin{array}{l}\text { Gas } \\
\text { welding }\end{array}$ & $\begin{array}{l}\text { Chi } \\
\text { square }\end{array}$ & P-value & Odds ratio & $\begin{array}{c}\text { Confidence } \\
\text { interval }\end{array}$ \\
\hline Pingueculum & 143 & 46 & 0.014 & 0.452 & 1.015 & $0.902-1.142$ \\
Pterygium & 55 & 16 & 0.124 & 0.368 & 1.039 & $0.901-1.197$ \\
$\begin{array}{l}\text { Cornea opacity } \\
\text { Pigmentary ma- }\end{array}$ & 34 & 3 & 5.266 & 0.007 & 1.256 & $1.118-1.410$ \\
$\begin{array}{l}\text { cular changes } \\
\text { Macular drusen }\end{array}$ & $16(5.8)$ & 0 & 5.664 & 0.003 & 1.357 & $1.274-1.445$ \\
\hline
\end{tabular}


Table 3: Age specific distribution of eye diseases

\begin{tabular}{|c|c|c|c|c|c|c|c|}
\hline Eye disease & $\leq 20 \mathrm{yrs}$ & $21-30 y r s$ & $31-40 \mathrm{yrs}$ & $41-50 \mathrm{yrs}$ & $51-60 y r s$ & $>60 \mathrm{yrs}$ & $\begin{array}{l}\text { Total no of } \\
\text { affected } \\
\text { workers }\end{array}$ \\
\hline \multicolumn{8}{|l|}{ Lids } \\
\hline Ptosis & - & 2 & 1 & - & - & - & $7(1.7 \%)$ \\
\hline Cyst of moll & - & 1 & - & - & - & - & $1(0.2 \%)$ \\
\hline Symblepharon & - & 1 & - & - & - & - & $1(0.2 \%)$ \\
\hline \multicolumn{8}{|l|}{ Conjunctiva } \\
\hline Conjunctivitis & - & 3 & - & - & - & - & $3(0.7 \%)$ \\
\hline Pingueculum & 1 & 45 & 81 & 37 & 29 & 10 & $203(50.1)$ \\
\hline Pterygium & - & 13 & 14 & 23 & 17 & 4 & $71(17.5 \%)$ \\
\hline \multicolumn{8}{|l|}{ Cornea } \\
\hline Opacity & - & 6 & 19 & 11 & 3 & 3 & $42(10.4 \%)$ \\
\hline pseudogerontoxon & - & - & 2 & - & - & - & $2(0.5 \%)$ \\
\hline \multicolumn{8}{|l|}{ Lens } \\
\hline Cataract & - & - & 2 & 7 & 22 & 16 & $47(11.6 \%)$ \\
\hline \multicolumn{8}{|l|}{ Optic nerve } \\
\hline Glaucoma suspect & 2 & 14 & 14 & 4 & 7 & 7 & $48(11.9 \%)$ \\
\hline \multicolumn{8}{|l|}{ Retina } \\
\hline pigmentary macular changes & - & 7 & 1 & 15 & 6 & 2 & $31(10.6 \%)$ \\
\hline macula drusens & - & 1 & 11 & 3 & 6 & - & $21(5.2 \%)$ \\
\hline Refractive errors & - & 15 & 21 & 24 & 26 & 16 & $102(25.2 \%)$ \\
\hline presbyopia & - & - & 26 & 51 & 51 & 20 & $149(36.8 \%)$ \\
\hline $\begin{array}{l}\text { Anophthalmic socket } \\
\text { (post enucleation) }\end{array}$ & - & - & 1 & - & - & - & $1(0.2 \%)$ \\
\hline
\end{tabular}

\section{Discussion}

Pingueculum was found in about $50 \%$ of the welders examined. It constituted the highest percentage of eye disorders found among the welders. This is similar to the reports by Doughty and Oblak ${ }^{23}$ who observed a greater likelihood of welders to develop pingueculum rather than pterygium. It is however contrary to the report of Ichiro ${ }^{24}$ who reported a higher prevalence of pterygium among welders in Japan. Differences in succeptibility and additional climatic differences have also been proposed as possible explanations for this variation ${ }^{23}$ Pterygium was the second common eye disorder among the welders in this study with a prevalence of $17.5 \%$.

Exposure to ultraviolet light, chronic irritation, windy condition and outdoor work have been documented as risk factors in the development of pterygia. ${ }^{25}$, In a review of the risk factors for pterygium, it was observed that certain occupations such as welders and saw-mill workers have a higher prevalence of pterygium and pingueculum. ${ }^{28}$ Alakija $^{29}$ in a work done in Benin City, Nigeria reported a statistically significant high prevalence of pterygium among welders compared with drivers. It has been proposed that it is likely associated with the additional ultraviolet radiation to which welders are exposed ${ }^{29}$. A statistically significant association found between duration of practice of welding and the occurence of pterygium was similar to the report of Ichiro Karai et $\mathrm{al}^{24}$ in Japan and Alakija ${ }^{29}$ in Benin.

The prevalence of corneal opacity 42 $(10.4 \%)$ was higher than what had previously been reported in Nigeria by Alakija $(1 \%)^{29}$, Okoye $(2.7 \%)^{31}$ and Aigbotsua $(0.5 \%)^{32}$ in their studies. This could be due to the fact that other industrial workers were included in those studies. Corneal opacity is a significant cause of blindness in the developing world, with corneal infections being responsible for a large proportion of the corneal scarring ${ }^{33}$. Cornea opacity in all affected welders was secondary to past ocular injuries with previous superficial foreign body from metal chips and burns from arc rays during grinding and welding activities. None of the 
cornea opacities was associated with visual impairment.

Thirty one $(7.7 \%)$ of the welders had pigmentary changes on the macular out of which one was blind accounting for $0.2 \%$ prevalence of blindness among the welders in Ile- Ife. A significant relationship was found between the likelihood of developing macular pigmentary changes and employment of arc welding relative to gas welding $(p<0.05\}$. These changes could be due to the thermal effect of ultraviolet radiation ${ }^{18-21}$ emissions which have been reported to be very high from arc welding. ${ }^{35}$

A statistically significant association was found between macular drusen and the use of arc welding $(\mathrm{P}<0.05)$. More than half of them were in people less than 40years (table 4).Exposure to welding has been found to be a significant risk for the development of macular drusen ${ }^{36}$ among welders. The possible mechanism underlying the retinal damage in welders has been proposed to include phototoxic reaction between visible light and phospholipids of retinal pigments which generates reactive oxygen intermediates. ${ }^{37}$

No defective macular function was observed with Amsler grid apart from the single case of bilateral maculopathy. Magnavita ${ }^{20}$ reported that most welders maculopathies are reversible or recover in a few months to a year but some cases show persistent retinal lesions that evolve to retinal atrophy and visual impairment.

Brittain ${ }^{19}$ reported two cases of retina burns caused by exposure to metal inert gas arc welding arcs. Fich et $\mathrm{al}^{39}$ reported 3 cases of maculopathy related to welding but there are no available reports in Nigeria.

About $81 \%$ of people with cataract were in the $50-70$ years age group. Two of those less than 50 years of age had traumatic cataract while others were of undetermined etiology. Exposure to ultraviolet rays is a known risk factor for the development of cataracts ${ }^{19}$. Alakija ${ }^{29}$ reported nine cases $(2.3 \%)$ of cataracts out of 400 welders in Benin City. Worldwide, cataract remains the leading cause of blindness. ${ }^{34,42-44}$

A prevalence of $25.2 \%$ was found with uncorrected refractive errors of various types. Presbyopia was observed in $36.8 \%$ of the welders all of whom were from the fourth decades and above. Out of the 149 welders with presbyopia, $52(34.9 \%)$ of them were uncorrected. Sadly enough, out of the 58 welders who wore reading glasses, only $7(12.1 \%)$ obtained them after proper eye examination by an ophthalmologist. A larger percentage $(72.4 \%)$ obtained theirs over the counter while the other $8(13.8 \%)$ got from either an optometrist, or an optician. Eye examination by an ophthalmologist prior to spectacle acquisition is an opportunity for possible early detection of glaucoma and prevention of blindness. Acquisition of reading glasses over the counter should be discouraged. Optic disc cupping suggestive of glaucomatous optic neuropathy was observed in 45 welders $(11.9 \%)$. There have not been reports associating disc cupping with ultraviolet radiation exposure even though the aetiopathogenesis of glaucoma is still evolving. All with such suspicious discs were however referred to a tertiary centre for full glaucoma work-up.

This study shows that Pingueculum, Pterygium, corneal opacity, and pigmentary macular deposits were the common eye disorders among welders in Ile-Ife. There is a very high prevalence of uncorrected refractive error among the welders.

\section{Conclusion}

Welders should be given health education on the potential ocular hazards of the different aspects of their occupation from time to time. The need for regular eye check and utilization of ophthalmic eye care services should be emphasized to all welders.

\section{References}

1. Kozlowski C. Ultraviolet radiation emitted by selected sources at work stands. International Journal of Occupational Medicine and Environmental Health 2001; 14: 287-292.

2. Moss CE, Murray WE. Radiation levels in gas welding, torch brazing and oxygen cutting. Welding Journal 1979; 9:37-46.

3. Emmet E.A, Horstman SW. Factors influencing the output of ultraviolet radiation during welding. Journal of Occupational Medicine 1976; 18:41-44.

4. Okuno T, Ojima J, Saito H. Ultraviolet radiation emitted by $\mathrm{CO}_{2}$ arc welding. Ann Occupational Hyg 2001; 45: 597-601.

5. Erhabor GE, Fatusi AO, Ndububa D. Pulmonary symptoms and functions in Gas welders in Ile Ife. Nigerian Medical Practitioner 1992; 24:99-101

6. 6. Pabley AS, Keeney AH. Welding processes and ocular hazards and protection. Ophthalmol 1981; 92: 77-84. 
7. Hinrichs JF. Safety and Health Project Committee on Radiation.Summary report. Welding Journal 1978; 57:62.

8. Klinwork G.K Chronic actinic keratopathy- a condition associated with conjunctival elastosis (pinguecula) and typified with characteristic extracellular concretions. Am J Pathol. 1972; 67:327-334.

9. Yuan LY, Hsing LL, Hung JL et al. Photokeratoconjunctivitis caused by different light sources. Amerian Journal of Emergency Medicine 2004; 22: 511-515.

10. 10.Dixon AJ and Dixon BF. Ultraviolet radiation from welding and possible risk of skin and ocular malignancy. Med J Aust 2004; 181: 155157.

11. Holly EA, Aston DA, Ahn DK. Smith AH, Intraocular melanoma linked to occupations and chemical exposures. Epidemiol 1996; 7: 55-61.

12. Guenel P. Laforest L, Cyr D et al. Occupational risk factors, ultraviolet radiation and ocular melanoma: a case control study in France. Cancer Causes Control 2001; 12: 451-459.

13. Vajdic CM, Kricker A, Giblin M et al. Sun exposure predicts risk of ocular melanoma in Australia. Int J Cancer 2002; 101: 175-182.

14. Ewing MR. The significance of a single injury in the causation of basal cell carcinoma of the skin. ANZ J Surg 1971; 41: 140-147.

15. 15.Zigmman S, Schults J, Yulo T. Possible roles of near UV in the cataractous process. Exp. Eye Res 1973; 15: 201-208.

16. Ham, W.T, Mueller, H.A, Rufollo H. H and Clarke A.M. Sensitivity of the retina to radiation damage as a function of wavelength. Photochem. Photobiol. 1979; 29:735.

17. Zaborski L. Studies of the visible spectrum of the welding arc. Bull inst. Marit Trop. Med. Gdynia 1976; 27:276.

18. Turut P, Isorni MC, Sicard C et al. Macular photoinjury caused by a welding arc on an eye with an implant. Bull Soc Ophthalmol France 1986; 86: 857-859.

19. Brittain GP: Retinal burns caused by exposure to MIG-welding arcs: report of two cases. $\mathrm{Br}$. J. Ophthalmol 1988: 72: 570-575.

20. Magnavita N. Photoretinitis: an underestimated occupational injury. Occup Med 2002; 52: 223225.

21. Calkins, JL, Hochheimer, BF. Retinal light exposure from ophthalmoscopes slit lamps and overhead surgical lamps. An analysis of potential hazards. Invest Ophthalmol V is Sci 1980; 19: 1009. African Health Sciences Vol 12 No 2 June 2012
22. Pabley SA, Keeney HA. Welding process and ocular hazards and new protective devices. Indian J Opbthalmol 1984; 32: 347-349.

23. Doughty MJ, Oblak E. A clinical assessment of the anterior eye in arc welders. Clinical Experimental Optometry 2005; 88(6): 387-595.

24. Ichiro K and Shun'lchi H. Pterygium in welders. British J Ophthalmol 1984; 68: 347-349.

25. Ashaye A.O Pterygium in Ibadan. West Afr J Med.1991; 10(3):232-243

26. Osahon A.I, Edema O.T. Pterygium in Benin City, Nigeria- A hospital based study. Nig J Surg. 1998; 5(2):77-80

27. Cameron M. Pterygium throughout the world. Springfield, IL: Charles C Thomas, 1965.

28. Rethy I, Fregene A.O, Salomon K. Postoperative beta irradiation of Pterygium in Nigeria. Nig. Med.J 1973;3(4):196-7

29. Alakija W. Eye morbidity among welders in Benin City Nigeria. Public Health 1988; 102(4): 381-384.

30. Saw S, Tan D. Pterygium: prevalence, demography and risk factors. Ophthalmic Epid. 1999;6(3):219- 228

31. Okoye O.I, Umeh R.E Eye health of industrial workers in southeastern Nigeria. West Afr J Med 2002; 21:132-137.

32. Aigbotsua P. Pattern of ocular disorders among technical workers in Ughelli North Local Government Area of Delta State. A dissertation submitted to the National Postgraduate Medical College of Nigeria. May 2003.

33. Prashant G, Gullapalli N. Corneal Ulcers; diagnosis and management. Community Eye Health 1999; 12:21-23.

34. Adeoye AO. Survey of blindness in rural communities of Southwestern Nigeria. Trop Med Int. Health1996;1:672-676.

35. World Health Organization. Environmental Health Criteria 160: Ultraviolet Radiation.WHO, Geneva. 1994: 15-43

36. Eun AK, Byung-Gyu K, Cheol-Ho Yi et al. Macular degeneration in an Arc Welder. Industrial Health 2007; 45:371-373.

37. Ambati J, Ambati BK, Yoo SH, Ianchulev I, Adamis AP. Age related macular degeneration : etiology, pathogenesis and therapeutic strategies. Survey ophthalmol 2003; 48:257-293.

38. Gos R, Stepien J, Horaski P- State of the eyes in welders of division M-5 Brown Coal Mine in Belchatow. Med Pr 1984; 35; 133-136. 
39. Fich M, Dahl H, Fledelius $H$ et al. Maculopathy caused by welding arcs. A report of 3 cases. Acta Ophthalmol Copenh 1993; 71:402-404.

40. Cellini M,Profazio V, Fantaguzzi P et al. Photic maculopathy by arc welding. A case report. Int Ophthalmol 1987; 10:157-159.

41. Ukponwan CU, Dawodu OA, Ayanru JO. Solar retinopathy in Benin City, Nigeria. West Afr J Med. 2003; 22:356-357.
42. World Health Organisation, Data on blindness throughout the world. W.H.O chronicle 1979; 33: 275-283.

43. Olurin O. Causes of blindness in Nigeria, a study of 1000 hospital patients. West Afr J Med 1973; 22:97-106.

44. National Committee for prevention of blindness, Kaduna. Data on blindness prevalence in Nigeria from community based surveys 1996.

45. Akinsola FB, Majekodunmi AA, Obowu CB, Ekanem EE. Pattern of eye diseases in adults $16 y e a r s$ and above in Ikeja and Alimoso Local Government Areas of Lagos state. The Nigeria Postgrad. Med. J 1995; 2:56-61. 